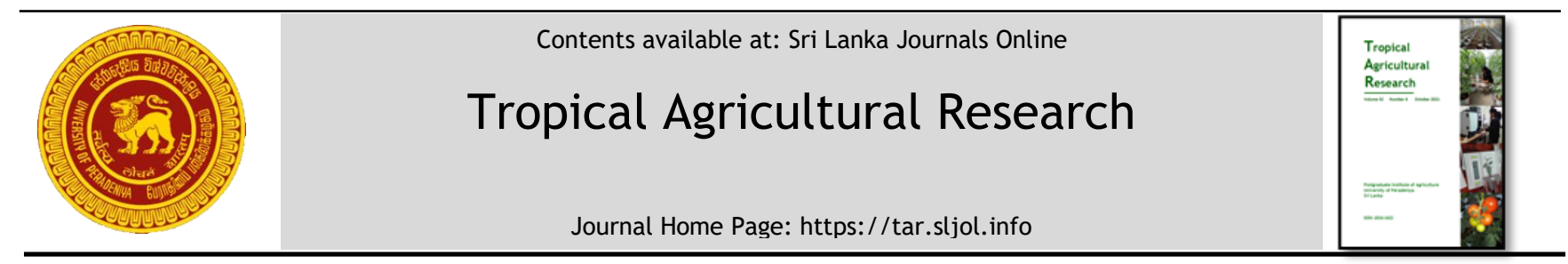

\title{
Comparative Advantage of Edible Oil Production in South Asia: An Assessment Using the Policy Analysis Matrix
}

\author{
S. Sahibzada ${ }^{1 *}$, D. Hemachandra ${ }^{1,2}$, S.A. Weerasooriya ${ }^{1,2}$, J. Weerahewa ${ }^{1,2}$ \\ ${ }_{1}^{1}$ Postgraduate Institute of Agriculture, University of Peradeniya, Peradeniya, 20400, Sri Lanka. \\ ${ }^{2}$ Department of Agricultural Economics and Business Management, Faculty of Agriculture, University of Peradeniya. \\ Peradeniya, 20400, Sri Lanka.
}

\section{ARTICLE INFO}

\section{Article history:}

Received: 15 August 2020

Revised version received: 17 July 2021

Accepted: 06 August 2021

Available online: 01 October 2021

\section{Keywords:}

Comparative advantage,

Edible oil

GTAP database policy

Analysis matrix

South Asia

\section{Citation:}

Sahibzada, S., Hemachandra, D., Weerasooriya, S.A. and Weerahewa, J. (2021). Comparative advantage of edible oil production in South Asia: An assessment using the policy analysis matrix. Tropical Agricultural Research, 32(4): 488-502.

DOI: http://doi.org/10.4038/tar.v32i4.8517

Sahibzada, S. (iD)

https://orcid.org/0000-0002-8246-0072

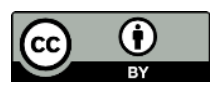

\section{ABSTRACT}

There is growing interest and efforts by the governments of South Asian countries to improve the competitiveness of domestic edible oil production with the objective of substituting for imports. This study evaluates and compares the comparative advantage and social profitability of the production of edible oils in Bangladesh, India, Pakistan, and Sri Lanka using the Policy Analysis Matrix (PAM) approach. The data required for this analysis were obtained from the InputOutput (I-O) table of the Global Trade Analysis Project (GTAP) Database (Version 10). Edible oils include animal fats, vegetable oils, margarine, and oil cake. Plant and animal sources, extraction, wearing, and electronic manufactures were treated as tradable inputs, while labor and capital were treated as nontradable inputs. Results revealed that edible oils output is highly protected in Bangladesh while the inputs are highly protected in Pakistan. Production of edible oils, is a socially profitable activity in India, Pakistan, and Sri Lanka and they have a comparative advantage which is attributed to the low cost of non-tradable inputs. Conversely, edible oil production is not socially profitable in Bangladesh and the social cost of nontradable inputs is higher than those of other inputs. It shows that Bangladesh does not have a comparative advantage in edible oil production. Inputs extracted from plant sources are highly taxed in Pakistan, and hence its comparative advantage is not revealed in export statistics. It is recommended that distortions in edible oil industry be removed to realize its comparative advantage.

\footnotetext{
*Corresponding author: sara.sahibzada.fazli@gmail.com
} 


\section{INTRODUCTION}

Consumer demand for edible oils has been rising with rising population and income. Edible oils produced from animal sources (such as fish, bovine, goat, pig, and poultry) and plant sources (such as palm, sunflower, soybean, olive, coconut, and cottonseed) have high global demand. Indonesia, Malaysia, Ukraine and Netherlands are the biggest producers of edible oils in the world (UN Comtrade, 2020). The export value of edible oils in the world was USD 101 billion in 2020, which is more than a fivefold increase from USD 20 billion in 2001. China, India, and the USA are the major importers. South Asian exports constituted only 1.93 percent of the global export of edible oils but South Asia contributed to approximately 14.2 percent of world edible oil imports in 2020 (UN Comtrade, 2020).

Edible oil imports have increased in developing countries while it has been stagnant in developed countries (Regmi and Gehlhar, 2001; Sahibzada et al., 2020). South Asia is unable to meet domestic demand with domestic production hence a substantial percentage of edible oil demand is met from imports (Chand, 2012). This means draining of foreign exchange from South Asia. Therefore, policymakers in most South Asian countries take measures to expand the domestic edible oil production to substitute for imports and promote exports (Mgeni et al., 2018). South Asian countries are partners of bilateral Free Trade Agreements (FTAs) which could be used as a platform to liberalize edible oil trade. Moreover, South Asian countries obtained membership in the World Trade Organization (WTO) and accelerated efforts for establishing multilateral FTAs in order to liberalize their trade (Chand et al., 2004). However, lately, some South Asian countries have imposed trade restrictions to protect local producers. India raised its import tax on refined palm oil to 54 percent and withdrew from importing edible crude oils. Conversely, Sri Lanka has introduced a 25 percent import tax on edible crude oil. Pakistan increased import duties of soybean and palm oils by 30 percent. Interestingly, there is no import duty on edible oil imports in Bangladesh. These policies have implications on the comparative advantage and the social profitability of edible oil production in these countries.

Many researchers have evaluated the comparative advantage of edible oil exports using the Revealed Comparative Advantage (RCA) measure. Samaratunga and Thibbotuwawa (2006), employing RCA claimed that Sri Lanka is competitive in producing oilseeds and has a strong comparative advantage in the export of coconut oil while exhibiting room to grow. Using the same method, Sachithra et al. (2014), in contrast, reported that Sri Lanka has lost its competitiveness and export specialization in oilseed production. According to Shinoj and Mathur (2008) based on RCA results, India was able to maintain its comparative advantage in the export of edible oils. Sultan and Zainal Abidin (2017) found that Pakistan has a comparative advantage in exporting edible oils to the USA. Although RCA is an appropriate means for measuring comparative advantage and the data required are easily available and complete, it cannot evaluate comparative advantage explicitly considering economic policies enacted. Therefore, some studies have evaluated the level of protection and comparative advantage of different edible oil products under market distortions using thePolicy Analysis Matrix (PAM). For example, Miah and Rashid (2015) and Dey et al. (2013) used PAM and found that Bangladesh has a comparative disadvantage in the production of mustard. Further Shah et al. (2013), using PAM, claimed that the production of sunflower seeds is a socially profitable activity in Pakistan.

The objective of this study is to evaluate and compare the comparative advantage and social profitability of edible oil production in South Asian countries: Bangladesh, India, Pakistan, and Sri Lanka using the PAM framework for the year 2014. The remainder of this paper is organized as follows: the second section presents an overview of the edible oil trade in South Asia. A review of the literature on PAM is then presented in the third section. The fourth section focuses on the method of analysis and data sources. Results and discussion are presented in the fifth section, while the final section offers conclusions and recommendations.

\section{An overview of the trade profile of edible oils in south Asian countries}

An overview of the edible oil trade is provided in this section using data available in the Global Trade Analysis Project (GTAP, version 10) database for 2014. Other oils category which include animal or vegetable fats or oils and their fractions is the major edible oil category exported from Bangladesh, India, and Pakistan, which accounted for $61.39,89.69$, and 99.67 percent of edible oil exports respectively. Mustard oil is the second most important edible oil exported from Bangladesh. Coconut oil accounted for 90.91 percent of edible oils exported from Sri Lanka (Table 1). Moreover, all South Asian countries have imported a substantial amount of palm oil 
Table 1. Major types of edible oils exported from South Asian countries in 2014 (Percentage)

\begin{tabular}{lccccccccc}
\hline Country & $\begin{array}{c}\text { Animal } \\
\text { fats }\end{array}$ & $\begin{array}{c}\text { Soybean } \\
\text { oil }\end{array}$ & $\begin{array}{c}\text { Groundnut } \\
\text { oil }\end{array}$ & $\begin{array}{c}\text { Olive } \\
\text { oil }\end{array}$ & $\begin{array}{c}\text { Palm } \\
\text { oil }\end{array}$ & $\begin{array}{c}\text { Sunflower } \\
\text { oil }\end{array}$ & $\begin{array}{c}\text { Coconut } \\
\text { oil }\end{array}$ & $\begin{array}{c}\text { Mustard } \\
\text { oil }\end{array}$ & $\begin{array}{c}\text { Other } \\
\text { oils }\end{array}$ \\
\hline Bangladesh & 0.15 & 0.00 & 0.00 & 0.01 & 0.00 & 0.07 & 0.28 & 38.11 & $\mathbf{6 1 . 3 9}$ \\
India & 4.28 & 0.07 & 2.26 & 0.02 & 0.02 & 0.52 & 2.65 & 0.50 & $\mathbf{8 9 . 6 9}$ \\
Pakistan & 0.00 & 0.00 & 0.03 & 0.10 & 0.00 & 0.02 & 0.01 & 0.17 & $\mathbf{9 9 . 6 7}$ \\
Sri Lanka & 0.00 & 0.00 & 0.00 & 0.00 & 0.66 & 0.00 & $\mathbf{9 0 . 9 1}$ & 0.00 & 8.43 \\
\hline
\end{tabular}

Source: Compiled by the authors based on data downloaded from Trade Map in 2020.

Table 2. Major types of edible oils imported by South Asian countries in 2014 (percentage)

\begin{tabular}{|c|c|c|c|c|c|c|c|c|c|}
\hline Country & $\begin{array}{c}\text { Animal } \\
\text { fats }\end{array}$ & $\begin{array}{c}\begin{array}{c}\text { Soybean } \\
\text { oil }\end{array} \\
\end{array}$ & $\begin{array}{c}\text { Groundnut } \\
\text { oil }\end{array}$ & $\begin{array}{c}\text { Olive } \\
\text { oil }\end{array}$ & $\begin{array}{c}\text { Palm } \\
\text { oil }\end{array}$ & $\begin{array}{c}\text { Sunflower } \\
\text { oil }\end{array}$ & $\begin{array}{c}\begin{array}{c}\text { Coconut } \\
\text { oil }\end{array} \\
\end{array}$ & $\begin{array}{c}\text { Mustard } \\
\text { oil }\end{array}$ & $\begin{array}{c}\begin{array}{c}\text { Other } \\
\text { oils }\end{array} \\
\end{array}$ \\
\hline Bangladesh & 0.11 & 29.94 & 0.00 & 0.04 & 68.84 & 0.07 & 0.58 & 0.02 & 0.40 \\
\hline India & 0.05 & 18.65 & 0.00 & 0.41 & 61.55 & 14.41 & 2.16 & 2.23 & 0.54 \\
\hline Pakistan & 1.08 & 5.57 & 0.00 & 0.37 & 90.39 & 0.02 & 0.94 & 0.00 & 1.63 \\
\hline Sri Lanka & 2.26 & 0.20 & 0.00 & 0.30 & 73.82 & 0.75 & 3.87 & 0.18 & 18.63 \\
\hline
\end{tabular}

Source: Compiled by the authors based on data downloaded from Trade Map in 2020.

ranging from 60-90 percent of the total edible oil imports. Imports of soybean oil follow palm oil in Bangladesh, India, and Pakistan, whereas other oils follow palm oil imports in Sri Lanka occupying 18.63 percent of imported edible oils in the country (Table 2).

India accounted for the largest trade value in edible oils compared to other South Asian countries. Imported value is higher compared to edible oil exports in India (Table 3). The trade balance of edible oils was negative in the four South Asian countries, i.e., the four countries had a trade deficit in edible oil trade - the highest being in India followed by Pakistan and Bangladesh. According to Figure 1, India and Sri Lanka focused more on the export of edible oils to destinations beyond the South Asian region. China, Iran, France, and Korea are the major importers of India's edible oils, while Canada, the USA, Australia, UK, and Germany are the major importers of Sri Lanka's edible oils. On the contrary, Bangladesh and Pakistan have concentrated more within the South Asian region. India and Afghanistan were the major importers of Bangladesh's and Pakistan's edible oils respectively (Figure 1).

Indonesia was the major exporter of edible oil to Bangladesh, India, and Pakistan with 46.8, 38.6, and 53.7 percent of the total edible oil imports of these countries respectively. Malaysia, Argentina, and Brazil were the other major exporters of edible oil to Bangladesh, India, and Pakistan. Malaysia, India, Indonesia, and the USA were the major exporters of edible oils to Sri Lanka, and they accounted for $45,17.6,17.1$, and 12.9 percent of total edible oil imports respectively (Figure 2)

Table 3. Trade of edible oils in South Asian countries with the World in 2014 (USD million).

\begin{tabular}{lccc}
\hline \multicolumn{1}{c}{ Country } & Exports & Imports & Trade Balance \\
\hline Bangladesh & 12.6 & $1,732.5$ & $-1,719.9$ \\
India & $2,784.2$ & $10,124.2$ & $-7,339.9$ \\
Pakistan & 169.1 & $2,507.9$ & $-2,338.9$ \\
Sri Lanka & 70.8 & 238.5 & -167.6 \\
\hline
\end{tabular}

Source: Authors computations using trade data extracted from GTAP Database, Version 10. 
A

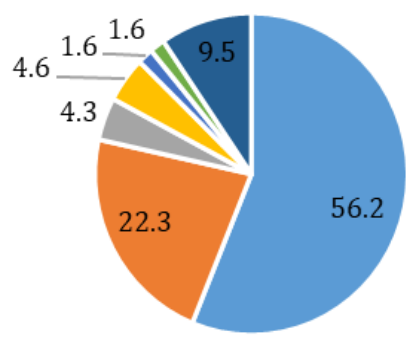

$$
\begin{array}{ll}
\text { - India } & \text { "Saudi Arabia } \\
\text { " UAE China } \\
\text { - ROW }
\end{array}
$$

C

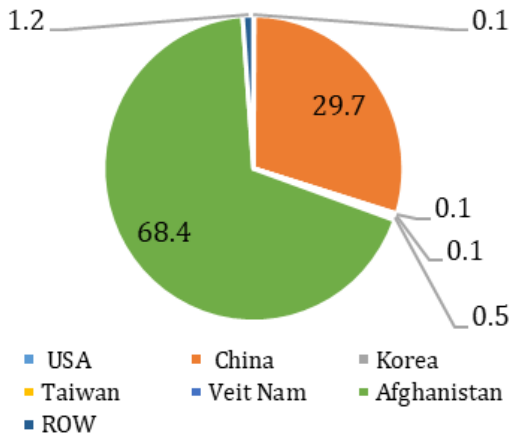

B

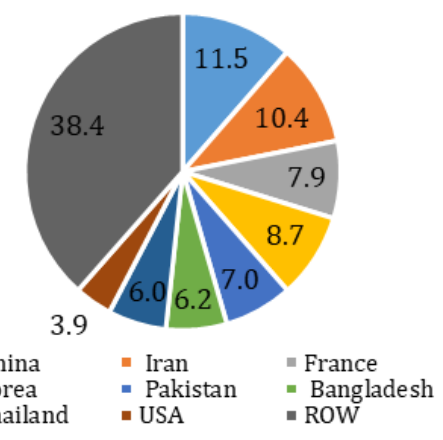

D

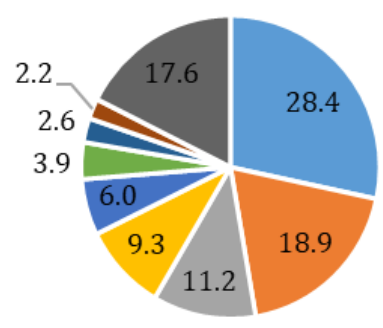

$\begin{array}{lll}\text { " Canada } & \text { " USA } & \text { " Australia } \\ \text { " UK } & \text { " Germany } & \text { " Japan } \\ \text { - Sweden } & \text { " Netherlands } & \text { " ROW }\end{array}$

Figure 1. Major importers of edible oils from South Asian countries in 2014. Panel (A) Bangladesh, Panel (B) India, Panel (C) Pakistan, and Panel (D) Sri Lanka

Source: Authors computations using trade data extracted from GTAP Database, version 10.

$\mathbf{A}$

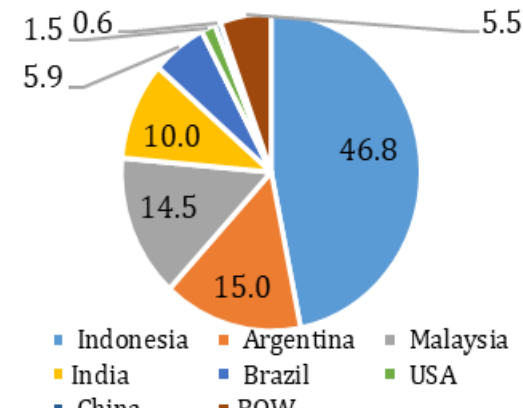

C

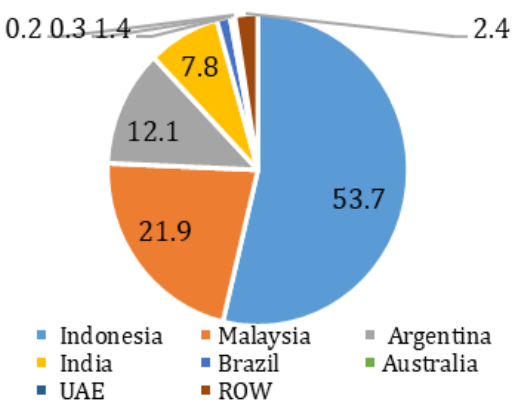

B

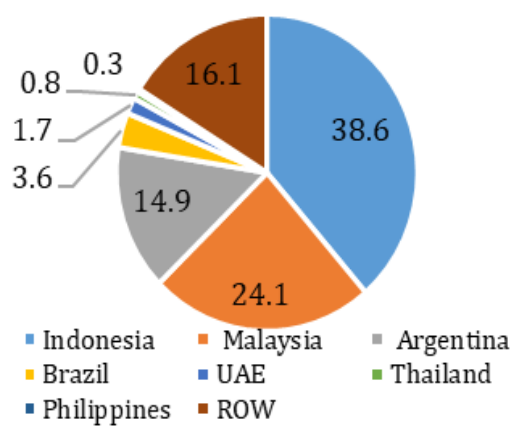

D

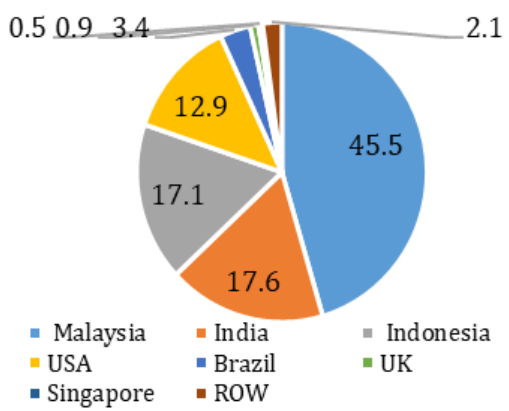

Figure 2. Major exporters of edible oils to South Asian countries in 2014. Panel (A) Bangladesh, Panel (B) India, Panel (C) Pakistan, and Panel (D)

Source: Authors computations using trade data extracted from GTAP Database, version 10. 
Table 4. Ad valorem rate of import tax (percentage) on edible oils in South Asian countries in 2014

\begin{tabular}{lcccccccccc}
\hline \multirow{2}{*}{ Importers } & \multicolumn{10}{c}{ Exporters $^{\dagger}$} \\
\cline { 2 - 11 } & BGD & IND & PAK & LKA & RSA & IDN & MYS & ARG & BRA & ROW \\
\hline Bangladesh & - & 10.9 & 0.00 & 6.25 & 8.96 & 0.00 & 0.32 & 0.00 & 0.00 & 4.26 \\
India & 0.06 & - & 4.99 & 0.39 & 6.08 & 0.99 & 0.00 & 20.6 & 20.6 & 5.94 \\
Pakistan & 0.00 & 8.03 & - & 1.61 & 3.50 & 2.31 & 0.00 & 0.00 & 0.00 & 0.33 \\
Sri Lanka & 2.68 & 0.25 & 3.29 & - & 6.89 & 0.00 & 3.12 & 0.00 & 0.00 & 1.69 \\
\hline
\end{tabular}

† BGD - Bangladesh, IND - India, PAK - Pakistan, LKA - Sri Lanka, IDN _ Indonesia, MYS - Malaysia, ARG, Argentina, BRA - Brazil, and ROW - Rest of the World

Source: Compiled by the Authors using tax data extracted from GTAP Database, version 10.

Bangladesh has highly taxed edible oils imported from India, Sri Lanka and the rest of South Asia while eliminating import taxes for Pakistan's edible oils due to the Pakistan-Bangladesh FTA. Pakistan has imposed lower import taxes on the ROW compared to South Asian countries. For example, Pakistan imposed the highest import tax on edible oil imports from India. Similarly, Sri Lanka imposed a relatively low percentage of import tax on edible oil imports from Indonesia, Argentina and Brazil, while it imposed higher taxes on edible oils imported from the rest of South Asia (Table 4). Indonesia, Malaysia, Argentina, and Brazil were the major import sources for importing edible oils to South Asia, and as Table 4 indicates, most South Asian countries removed import taxes for these countries. Only India taxed Argentina's and Brazil's edible oils (20.6 percent), Sri Lanka and Bangladesh taxed Malaysia's edible oils by 3.12 and 0.32 percent respectively. Import taxes on tradable inputs are presented in Appendix Table 5. India, Pakistan, and Sri Lanka implemented the highest import taxes on tradable inputs imported from Saudi Arabia, Indonesia, Malaysia, Argentina, and Brazil. Among all tradable inputs, inputs with plant sources and processed food were highly taxed compared to others in most South Asian countries considered.

\section{METHODOLOGY}

\section{Measuring comparative advantage using the Policy Analysis Matrix (PAM)}

The concept of the PAM was developed by Monke and Pearson (1989) and was augmented by the development in price distortion analysis by Masters and Winter-Nelson (1995) for measuring input use efficiency in production, comparative advantage, and the degree of government intervention. The theory of comparative advantage states that when a country produces a good or service for a lower opportunity cost than other countries, the trade will be mutually beneficial for both countries. Domestic Resource Cost (DRC) is an important index that can calculate comparative advantage taking into account all government policies. DRC can be calculated using a PAM. Government policies can affect the level of protection on agricultural production. PAM allows researchers to analyze the effects of such policies by constructing different enterprise budgets, one valued at market prices and the other valued at social prices. Moreover, the PAM framework is particularly useful in finding appropriate changes to production and trade policies (Gonzales et al., 1994). Since this study aims to analyze and compare comparative advantage, social profitability, and level of protection for domestic production of edible oils in South Asian countries, PAM is a suitable approach. Several recent studies have used PAM to measure comparative advantage and protection in edible oil production as shown in Table 5 (Khan, 2001; Shahabuddin and Dorosh, 2002; Akhtar et al., 2007; Kapaj et al., 2010; Quddus and Mustafa, 2011; Mamza et al., 2014).

\section{The PAM Framework}

The basic format of the PAM, as shown in Table 6, is a matrix of two-way accounting identities. The main steps in using the PAM method are: identifying the commodity systems, collecting representative budgets for each activity, calculating social or shadow values, rolling up the budgetary data into a matrix, analysing the matrix, and finally, simulating policy changes. The data in the first row provide a measure of private profitability (D), defined as the difference between observed revenue $(A)$ and costs $(B+C)$. 
Table 5. A review of literature on the application of PAM in edible oil production.

\begin{tabular}{|c|c|c|c|c|}
\hline Authors & Commodity & Country & $\begin{array}{l}\text { Study } \\
\text { Period }\end{array}$ & Key Results \\
\hline $\begin{array}{l}\text { Mahmood } \\
\text { (1991) }\end{array}$ & $\begin{array}{l}\text { Oilseeds and } \\
\text { edible oils }{ }^{\dagger}\end{array}$ & Pakistan & $\begin{array}{l}1978- \\
1988\end{array}$ & $\begin{array}{l}\text { Pakistan has a comparative advantage in the } \\
\text { production of oilseeds except for cottonseeds. } \\
\text { Production of sunflower and soybean oils } \\
\text { showed a significant comparative advantage } \\
\text { among all edible oils. This study concluded that } \\
\text { the indigenization of the oilseed and edible oil } \\
\text { industry is an economically efficient way of } \\
\text { saving foreign exchange. }\end{array}$ \\
\hline $\begin{array}{l}\text { Mane-Kapaj } \\
\text { et al. }(2010)\end{array}$ & Olive oil & Albania & $\begin{array}{l}2005- \\
2006\end{array}$ & $\begin{array}{l}\text { Although Albania does not have a comparative } \\
\text { advantage in olive oil production, it is still } \\
\text { profitable for producers. }\end{array}$ \\
\hline $\begin{array}{l}\text { Quddus and } \\
\text { Mustafa } \\
(2011)\end{array}$ & Cottonseed & Pakistan & $\begin{array}{l}2000- \\
2005\end{array}$ & $\begin{array}{l}\text { Pakistan enjoys a comparative advantage in } \\
\text { cottonseed production. Thus, an expansion in } \\
\text { cottonseed production for import substitution } \\
\text { is highly cost effective. }\end{array}$ \\
\hline $\begin{array}{l}\text { Miah and } \\
\text { Rashid } \\
(2015)\end{array}$ & $\begin{array}{l}\text { Mustard, } \\
\text { Sesame, } \\
\text { Groundnut, } \\
\text { and Soybean }\end{array}$ & Bangladesh & $\begin{array}{l}2009- \\
2010\end{array}$ & $\begin{array}{l}\text { Bangladesh has a comparative advantage in } \\
\text { producing oilseeds except for mustard for } \\
\text { import substitution since the DRC estimates } \\
\text { for selected oilseed crops were less than unity. }\end{array}$ \\
\hline $\begin{array}{l}\text { Mgeni et al. } \\
\text { (2018) }\end{array}$ & Edible oils & Tanzania & 2016 & $\begin{array}{l}\text { Domestic edible oil producers have a } \\
\text { comparative advantage but taxes on tradable } \\
\text { inputs render domestic edible oil producers } \\
\text { uncompetitive. }\end{array}$ \\
\hline
\end{tabular}

† Cottonseed, mustard, sesame, groundnut, and soybean seeds are sources of edible oils

Private profitability illustrates the competitiveness of the production system, given current technologies, prices for inputs and outputs, and policy. The second row of the matrix calculates the social profit $(\mathrm{H})$ that reflects social opportunity costs. Social profits measure efficiency and comparative advantage. In addition, a comparison of private and social profits provides a measure of policies effect. A positive social profit demonstrates that the country uses scarce resources efficiently and has a static comparative advantage in the production of that commodity at the margin. Similarly, negative social profits indicate that the sector is wasting resources that could have been utilized more efficiently in some other sector. In other words, the cost of domestic production exceeds the cost of imports, suggesting that the sector cannot survive without government support at the margin. The third row of the matrix estimates the difference between the first and second rows. The difference between private and social values of revenues, costs, and profits can be explained by policy interventions.

\section{Indicators of protection and comparative advantage}

The PAM framework can also be used to calculate a few other important indicators for policy analysis. The nominal protection coefficient (NPC), a simple indicator of the incentives or disincentives in place, is defined as the amount by which the private price deviates from its social price. It indicates the impact of policies and market failures that result in the divergence between the two prices. This can be calculated for the outputs as well as the inputs.

Nominal Protection Coefficient Output (NPCO) shows the extent to which private prices of outputs differ from social prices. A positive NPCO implies protection by policies and a positive incentive for the production of edible oils. This is given by:

$$
\mathrm{NPCO}=(\mathrm{A} / \mathrm{E})
$$

Nominal Protection Coefficient Input (NPCI) shows how the private price of tradable inputs differs 
Table 6. The Framework of Policy Analysis Matrix

\begin{tabular}{ccccc}
\hline \multirow{2}{*}{ Items } & \multirow{2}{*}{ Revenue } & \multicolumn{2}{c}{ Costs } & \multirow{2}{*}{ Profit } \\
\cline { 3 - 4 } & & Tradable Inputs & Non- Tradable Inputs & \\
\hline Private Price & $\mathrm{A}$ & $\mathrm{B}$ & $\mathrm{C}$ & $\mathrm{D}$ \\
Social Price & $\mathrm{E}$ & $\mathrm{F}$ & $\mathrm{G}$ & $\mathrm{H}$ \\
Divergence & $\mathrm{I}$ & $\mathrm{J}$ & $\mathrm{K}$ & $\mathrm{L}$ \\
\hline
\end{tabular}

Private profit (D) = A- $(\mathrm{B}+\mathrm{C})$; Social profit $(\mathrm{H})=\mathrm{E}-(\mathrm{F}+\mathrm{G})$; Output transfer $(\mathrm{I})$ = A-E; Input transfer $(\mathrm{J})$ = B-F; Factor transfer $(\mathrm{K})=\mathrm{C}-\mathrm{G}$; Net transfer $(\mathrm{L})=\mathrm{D}-\mathrm{H}$ or $\mathrm{I}-\mathrm{J}-\mathrm{K}$

Source: Monke and Pearson (1989).

from social price. A positive NPCI shows that the private price of tradable inputs is greater than comparable social prices indicating that the system is taxed. A negative NPCI indicates that the system is subsidized. This is defined as:

$$
\mathrm{NPCI}=(\mathrm{B} / \mathrm{F})
$$

The Effective Protection Coefficient (EPC)is the ratio of value-added in private prices (A-B) to value-added in social prices (E-F). An EPC greater than one implies that government policy protects the producers. This is given by:

$$
\mathrm{EPC}=(\mathrm{A}-\mathrm{B}) /(\mathrm{E}-\mathrm{F})
$$

DRC is the major indicator of comparative advantage and is widely used as a guide for policy reforms. It was first introduced by Bruno in 1965. It can be used to compare two countries that have a cost advantage in producing a specific product (Markou and Kavazis, 2006). The DRC denotes the connection between the opportunity cost of domestic resources and social value-added. In other words, DRC is the ratio of the social cost of non-tradable inputs of producing a particular product to the net foreign exchange earned by producing the good domestically. A DRC less than one indicates that the country has a comparative advantage in producing a particular commodity, whereas a DRC greater than one demonstrates a comparative disadvantage. This is defined as:

$$
\mathrm{DRC}=\mathrm{G} /(\mathrm{E}-\mathrm{F})
$$

\section{Data sources and social prices}

The Global Trade Analysis Project (GTAP) version 10 dataset comprises data on detailed bilateral trade, protection data, and input-output (I-O) data for the year 2014 (It is the most recent version of GTAP at the time of writing this paper). Edible oils are an aggregated sector in GTAP containing animal fats, vegetable oils, margarine and similar preparations, and oil cakes (See Appendix Table 1 for details). For PAM calculations, two types of prices, i.e., private and social prices are required.
Private price refers to the market price and Social price refers to the shadow price. The private costs needed for the study were obtained from the I-O table extracted from the GTAP database version 10 for 2014. In the first stage, all inputs were categorized into tradable and non-tradable inputs. Among the 65 sectors of GTAP database version 10,45 sectors were selected as tradable inputs because the prices of these inputs are determined in the world market. They are classified into six categories; plant sources, animal sources, food and beverage, extraction and heavy manufacture, wearing manufacture, and electronic manufacture. Appendix Table 2 illustrates the tradable inputs and their aggregation. Labor (skilled and unskilled) and capital were considered as major non-tradable inputs and the rest of the sectors that are not traded internationally such as electricity, water supply, all public services, hotel accommodation, real estate, construction, and local transportation were considered as minor non-tradable inputs.

As private values differ from their real social values due to distortions originating from market interventions or government protections, we need to calculate social values for all inputs and outputs. The approach presented by Saerbeck (1990) and Sartori (2014) was adopted for the calculation of social prices. Appendix 3 illustrates the methods used for the calculation of social prices. The social costs of tradable inputs, minor non-tradable inputs, and outputs were calculated using the Standard Conversion Factor (SCF). This method was first introduced by Little and Mirrlees (1994) and can be calculated from the average rate of import duty, export tax, and the difference between the world and domestic prices in a particular country (Squire and van der Tak, 1975; Bruce, 1976; Linn, 1977 and Weiss, 2009). Cost, Insurance and Freight (CIF), and Free on Board (FOB) prices were used for import and export prices respectively in the SCF formula. CIF, FOB value, import tax, and subsidy were gathered from the GTAP Database (version 10). In the case of major non-tradable inputs, the social costs of 
labor were calculated using the Shadow Wage Rate (SWR). There are two market scenarios for skilled labor; i) perfect market, ii) and imperfect market. For unskilled labor only, an imperfect market was considered. Therefore, the SWR for skilled labor was set to value 1 in the first scenario, while values 0.5 and 1.5 were applied in the second scenario. The Standard Exchange Rate Factor (SERF) was employed for the calculation of the social cost of capital. Appendix Table 4 shows the formulas and their components used for finding conversion factors.

\section{RESULTS AND DISCUSSION}

The production of edible oils has a different structure in different countries. This can be shown by the cost share of resources used in the production process and is represented in Table 7 for Bangladesh, India, Pakistan, and Sri Lanka. Non-tradable inputs have accounted for a large proportion of the cost compared to tradable inputs in all countries except Pakistan. Tradable inputs have accounted for 92.37 percent of the production cost in Pakistan while non-tradable inputs accounted for only 7.63 percent. Plant source inputs were dominant among six tradable inputs in all countries except India. This is because Pakistan, Sri Lanka, and Bangladesh spend a large proportion of the cost for purchasing oilseeds or vegetables and fruits from abroad or domestically. On the other hand, India largely imports edible crude oils and later processes them locally because Indian refineries have a comparatively high capacity to process edible oils. Interestingly, animal sources have accounted for 10 percent of total tradable inputs only in Sri Lanka. It shows that South Asian countries are mostly producing vegetable oils than animal oils.

Minor non-tradable inputs contributed to a large share of the total non-tradable inputs in Bangladesh, India, and Pakistan. This is due to the high costs arising from the accommodation of machinery, transport and electricity/gas. As edible oil production is fully mechanized, processing needs more accommodation and power for its machinery. Moreover, all countries in the study imported crude oil or oilseeds and later processed them. Owing to this, they incurred high costs in transportation, storage, and financial services.

Table 7. Production structure of edible oils in South Asia in 2014.

\begin{tabular}{|c|c|c|c|c|c|}
\hline \multirow{2}{*}{\multicolumn{2}{|c|}{ Type of input }} & \multicolumn{4}{|c|}{ Percentage share of the cost } \\
\hline & & \multirow{2}{*}{$\frac{\text { Bangladesh }}{64.43}$} & \multirow{2}{*}{\begin{aligned} \multicolumn{1}{l}{ India } \\
35.11\end{aligned}} & \multirow{2}{*}{$\begin{array}{r}\text { Pakistan } \\
98.66\end{array}$} & \multirow{2}{*}{$\begin{array}{r}\text { Sri Lanka } \\
84.27\end{array}$} \\
\hline Tradable & a - Plant source & & & & \\
\hline & b - Animal source & 0.001 & 0.94 & 0.07 & 10.22 \\
\hline & c - Food and Beverage & 33.69 & 52.22 & 0.43 & 2.58 \\
\hline & $\begin{array}{l}\mathrm{d} \text { - Extraction and heavy } \\
\text { manufacture }\end{array}$ & 1.56 & 7.00 & 0.50 & 2.79 \\
\hline & e - Wearing manufacture & 0.24 & 4.29 & 0.17 & 0.12 \\
\hline & f - Electronic manufacture & 0.08 & 0.43 & 0.16 & 0.02 \\
\hline & Total $(a+b+c+d+e+f)$ & 100.00 & 100.00 & 100.00 & 100.00 \\
\hline & $\begin{array}{l}\text { A - Share of total tradable } \\
\text { inputs from the total cost }\end{array}$ & 46.53 & 48.27 & 92.37 & 43.37 \\
\hline \multirow{6}{*}{$\begin{array}{l}\text { Non- } \\
\text { Tradable } \\
\text { Inputs }\end{array}$} & Un-Skilled & 2.24 & 0.59 & 0.37 & 0.34 \\
\hline & g-Labor Skilled & 22.10 & 9.14 & 12.35 & 7.78 \\
\hline & h-Capital & 33.70 & 29.98 & 32.13 & 64.80 \\
\hline & i- Minor non-tradable inputs & 41.96 & 60.29 & 55.15 & 27.07 \\
\hline & Total $(g+h+i)$ & 100.00 & 100.00 & 100.00 & 100.00 \\
\hline & $\begin{array}{c}\text { B - Share of total non-tradable } \\
\text { inputs from the total cost }\end{array}$ & 53.47 & 51.73 & 7.63 & 56.63 \\
\hline \multicolumn{2}{|c|}{ Total Cost $(A+B)$} & 100.00 & 100.00 & 100.00 & 100.00 \\
\hline
\end{tabular}

Source: Authors computations based on I-O table from the GTAP database, version 10.

Table 8. Revenue and cost of edible oil production in South Asia in 2014(USD million). 


\begin{tabular}{|c|c|c|c|c|c|}
\hline \multicolumn{2}{|c|}{ Edible Oils } & Bangladesh & India & Pakistan & Sri Lanka \\
\hline \multirow{2}{*}{ Revenue } & Private & $2,062.20$ & $38,523.91$ & $1,073.48$ & 484.29 \\
\hline & Social & $1,782.36$ & $35,330.01$ & $1,003.97$ & 452.10 \\
\hline \multirow{2}{*}{ Total Costs } & Private & $2,050.12$ & $35,875.22$ & 902.92 & 402.04 \\
\hline & Social & $1,891.77$ & $32,856.62$ & 532.74 & 369.29 \\
\hline \multicolumn{2}{|c|}{ Private profit } & 12.08 & $2,648.69$ & 170.56 & 82.25 \\
\hline \multicolumn{2}{|c|}{ Social profit } & -109.41 & $2,473.39$ & 471.23 & 82.81 \\
\hline \multicolumn{2}{|l|}{ NPCO } & 1.16 & 1.09 & 1.07 & 1.07 \\
\hline
\end{tabular}

Source: Authors computations based on Input-Output table from the GTAP Database, Version 10.

Edible oil production is a capital-intensive activity as is evident from the high percentage share of capital and low percentage share of labor. This implies that the edible oil industry is indulging in more labor displacing activities. Moreover, skilled labor was dominant in all four countries, which demonstrates that edible oil production is a technical procedure that requires more machinery and a skilled labor force.

Private and social revenue and costs are presented in Table 8 . The results reveal that edible oils are privately profitable in all four countries, with the highest being in India with USD 2,648.69 million followed by Pakistan, Sri Lanka, and Bangladesh with USD 170.56 million, 82.25 million, and 12.08 million respectively. NPCO values are greater than one for all countries indicating that the production of edible oils is protected in all countries. The highest protection was seen in Bangladesh (Table 8). The value of social profitability is presented in Table 8, revealing that edible oil production is socially profitable in all countries except Bangladesh. India gained the highest social profit with USD 2,081.4 million in 2014. Since edible oil production is distorted in South Asia through a myriad of input and output taxes and subsidies, the decision to expand production has direct implications on the level of social profitability. As results depict, India, Pakistan, and Sri Lanka were successful in gaining private and social profits in the presence of such policies. However, due to the high taxes imposed by the government on edible oil production Bangladesh's producers cannot gain social profits.

Table 9. Private and social costs of tradable inputs in producing edible oils in South Asia in 2014(USD million).

\begin{tabular}{llrrrr}
\hline \multicolumn{1}{c}{ Edible oils } & Cost type & Bangladesh & \multicolumn{1}{c}{ India } & Pakistan & Sri Lanka \\
\hline Plant Sources & Private cost & 614.53 & $6,080.25$ & 822.86 & 146.95 \\
& Social cost & 503.66 & $4,388.21$ & 454.49 & 121.27 \\
Animal Sources & Private cost & 0.01 & 163.56 & 0.62 & 17.83 \\
& Social cost & 0.01 & 148.41 & 0.58 & 16.27 \\
Food and Beverage & Private cost & 321.32 & $9,041.92$ & 3.55 & 4.49 \\
& Social cost & 277.70 & $8,199.10$ & 3.18 & 3.85 \\
Extraction and heavy & Private cost & 14.91 & $1,211.34$ & 4.21 & 4.87 \\
manufacture & Social cost & 12.79 & 916.43 & 3.28 & 3.99 \\
Wearing manufacture & Private cost & 2.29 & 743.68 & 1.40 & 0.21 \\
& Social cost & 1.86 & 586.14 & 1.15 & 0.16 \\
Electronic Manufacturer & Private cost & 0.80 & 74.53 & 1.37 & 0.03 \\
& Social cost & 0.74 & 62.37 & 1.17 & 0.03 \\
Total & Private cost & 954 & 17,315 & 834 & 174 \\
& Social cost & 797 & 14,301 & 464 & 146 \\
NPCI & & 1.20 & 1.21 & 1.80 & 1.20 \\
EPC & & 1.12 & 1.01 & 0.44 & 1.01 \\
\hline
\end{tabular}

Source: Authors computations based on Input-Output table from the GTAP database, version 10. 
Table 10. Private and social costs of non-tradable inputs in producing edible oils in South Asia in 2014 (USD million).

\begin{tabular}{|c|c|c|c|c|c|c|}
\hline \multicolumn{2}{|c|}{ Non-tradable inputs } & \multirow{2}{*}{$\begin{array}{r}\text { Cost type } \\
\text { Private cost }\end{array}$} & \multirow{2}{*}{$\begin{array}{r}\text { Bangladesh } \\
24.60\end{array}$} & \multirow{2}{*}{$\begin{array}{l}\text { India } \\
110.30\end{array}$} & \multirow{2}{*}{$\begin{array}{r}\text { Pakistan } \\
0.26\end{array}$} & \multirow{2}{*}{$\begin{array}{r}\text { Sri Lanka } \\
0.78\end{array}$} \\
\hline Labor & Un-skilled & & & & & \\
\hline & & Social cost & 23.37 & 107.24 & 0.24 & 0.72 \\
\hline & Skilled & Private cost & 242.23 & $1,696.28$ & 8.51 & 17.71 \\
\hline & & Social cost & 242.23 & $1,696.28$ & 8.51 & 17.71 \\
\hline \multirow{2}{*}{\multicolumn{2}{|c|}{ Capital }} & Private cost & 369.40 & $5,563.71$ & 22.14 & 147.52 \\
\hline & & Social cost & 369.40 & $5,563.15$ & 22.13 & 143.65 \\
\hline \multirow{2}{*}{\multicolumn{2}{|c|}{ Minor non-tradable }} & Private cost & 460.03 & $11,189.64$ & 38.01 & 61.64 \\
\hline & & Social cost & 460.02 & $11,189.64$ & 38.01 & 61.64 \\
\hline \multirow{2}{*}{\multicolumn{2}{|c|}{ Total non-tradable inputs }} & Private cost & $1,096.26$ & $18,559.94$ & 68.91 & 227.66 \\
\hline & & Social cost & $1,095.02$ & $18,556.31$ & 68.89 & 223.72 \\
\hline DRC & & & 1.11 & 0.88 & 0.13 & 0.73 \\
\hline
\end{tabular}

Source: Authors computations based on Input-Output table from the GTAP database, version 10 .

Private and social costs are separated into tradable and non-tradable inputs. They are displayed in Tables 9 and 10 respectively. According to Table 9, NPCI values are greater than one in all four countries, displaying that the tradable inputs have been taxed by all four governments in the production of edible oils in 2014. EPC was less than one and a huge gap between NPCI (1.80) and EPC (0.44) was observed in Pakistan, indicating that tradable inputs were taxed heavily in Pakistan, with the highest noted for plant source inputs.

All the results presented in the preceding section were related to the first scenario (perfect skilled labor market). In the second scenario, an imperfect skilled labor market was assumed and values 0.5 and 1.5 were assumed for SWR. In this scenario the only results which changed were the DRC ratio and social profitability of edible oil production. However, the results for the second scenario when SWR is equal to 0.5 revealed that edible oil production in all four countries is socially profitable. An interesting point is that edible oils were not socially profitable in Bangladesh under the perfect market scenario but under this assumption, the social profitability of Bangladesh switches from USD -109.41 million to USD 11.5 million. Similarly, the level of profits has increased in India, Pakistan and Sri Lanka compared to the perfect market scenario. It indicated that higher wages for skilled labor in a country compared to the world market can encourage people in that country to work in the country and it would directly affect the social profitability of the economy. Conversely, when SWR is assumed to be 1.5 , a sharp decrease in social profits in all four countries has been observed. It indicated that edible oil production is highly dependent on skilled labor. If wage for skilled labor increases in market price the skilled labor will move to some other place that pays more. This situation is harmful for edible oil production in South Asian countries. The results of DRC under the second scenario revealed that an imperfect skilled labor market does not affect patterns of comparative advantage in the four countries. Concerning the level of comparative advantage, only a slight change was observed compared to the first scenario. The lower social costs of skilled labor (higher private costs of skilled labor) tend to increase the level of comparative advantage and vice versa (Table 11).

Table 11. DRC ratio under imperfect skilled labor market in 2014

\begin{tabular}{lcccccccc}
\hline \multirow{2}{*}{ Indicators } & \multicolumn{2}{c}{ Bangladesh } & \multicolumn{2}{c}{ India } & \multicolumn{2}{c}{ Pakistan } & \multicolumn{2}{c}{ Sri Lanka } \\
\cline { 2 - 9 } & \multicolumn{2}{c}{ SWR } & \multicolumn{2}{c}{ SWR } & \multicolumn{2}{c}{ SWR } & \multicolumn{2}{c}{ SWR } \\
\cline { 2 - 9 } & $\mathbf{0 . 5}$ & $\mathbf{1 . 5}$ & $\mathbf{0 . 5}$ & $\mathbf{1 . 5}$ & $\mathbf{0 . 5}$ & $\mathbf{1 . 5}$ & $\mathbf{0 . 5}$ & $\mathbf{1 . 5}$ \\
\hline DRC (Ratio) & 0.99 & 1.23 & 0.84 & 0.92 & 0.12 & 0.14 & 0.70 & 0.76 \\
Social profit & 11.7 & -230.5 & 3321.5 & 1625.2 & 475.5 & 467.0 & 91.7 & 74.0 \\
(USD million) & & & & & & & &
\end{tabular}

Source: Authors computations based on Input-Output table from GTAP database, version 10 


\section{CONCLUSIONS}

The objective of this study was to evaluate and compare the comparative advantage and social profitability of edible oil production in South Asian countries: Bangladesh, India, Pakistan, and Sri Lanka using the PAM framework for the year 2014 using GTAP data version 10. The results for NPCO and NPCI indicated that inputs and outputs of edible oil production are protected in all South Asian countries. The highest protection for the output was observed in Bangladesh while inputs were highly protected by Pakistan. Tradable inputs coming from plant sources were highly taxed in Pakistan as evidenced by the large gap between the NPCI and the EPC. Results showed that edible oil production is a socially profitable activity in Pakistan, India, and Sri Lanka, while not so in Bangladesh. Furthermore, India shows the highest social profitability. Similarly, while they remain major importers of edible oils, India, Pakistan, and Sri Lanka have a comparative advantage in producing them. There is a disparity

\section{REFERENCES}

Akhtar, W., Sharif, M. and Akmal, N. (2007). Analysis of economic efficiency and competitiveness of the rice production systems of Pakistan's Punjab. Lahore Journal of Economics, 12(1), 141-153.

Balassa, B. (1965). Trade liberalization and "Revealed" comparative advantage. The Manchester school of economics and social studies, 33(2), 99-123.

Bruce, C. (1976). Social cost-benefit analysis: A guide for country and project economists to the derivation and application of economic and social accounting prices (No. SWP-239, p. 1). The World Bank.

Bruno, M. (1965). The optimal selection of exportpromoting and import-substituting projects. Project for quantitative research in economic development, center for international affairs, Harvard University.

Chand, R. (2012). International trade, regional integration and food security in South Asia with special focus on LDCS. UNCTAD and Common Wealth Secretariat. Background paper No. RVC4.

Chand, R., Jha, D. and Mittal, S. (2004). WTO and oilseeds sector: Challenges of trade liberalization. Economic and Political Weekly, 39(6), 533-537. between trade patterns and the comparative advantage of edible oils in Pakistan, India, and Sri Lanka. The reduction or removal of taxes on tradable inputs is recommended for these countries to realize their comparative advantage. Moreover, the expansion of edible oil production in these countries can help substitute imported edible oils. Thus, these three countries need to pay more attention in investing in this sector. The same cannot be recommended for Bangladesh as the production of edible oils is currently not a socially profitable activity. Moreover, as edible oil production is a capital-intensive activity, and capital is substituted for labor, expansion of production is beneficial for countries with high labor costs. This would, however, lead to increased unemployment.

\section{ACKNOWLEDGMENTS}

This study was carried out with the financial support of the SAARC Agricultural Center (SAC), Dhaka, Bangladesh.

Dey, N. C., Bala, S. K., Islam, A. K. M. S. and Rashid, M. A. (2013). Sustainability of groundwater use for irrigation in northwest Bangladesh. National Food Policy Capacity Strengthening Program (NFPCSP), Food Planning and Monitoring Unit (FPMU), ministry of food, FAO-Bangladesh, Dhaka.

Gonzales, L.A., Kasryno, F., Perez, N.D. and Rosegrant, M.W. (1994). Economic incentives and comparative advantage in Indonesian food crop production (Research Report 93). Washington, DC: International food policy research institute.

Khan, N. P. (2001). Comparative advantage of wheat production in Pakistan and its policy implications. Pakistan Journal of Agricultural Economics, 4(2), 17-29.

Linn, R. L. and Slinde, J. A. (1977). The determination of the significance of change between pre-and post-testing periods. Review of Educational Research, 47(1), 121-150.

Little, I.M.D. and J.A. Mirrlees. (1974). Project appraisal and planning for developing countries. New York: Basic Books.

Mahmood, A. (1991). Assessing the comparative advantage of Pakistan's oilseed and edible oil industry. A thesis presented to the University of Manitoba in fulfillment of the thesis requirement for the degree of $\mathrm{Ph}$. $\mathrm{D}$ in Economics. 
Mamza, A. O., Salman, K. K. and Adeoye, I. B. (2014). Competitiveness of beef processing in Borno state of Nigeria: a policy analysis matrix approach. Journal of Agriculture and Sustainability, 6(2), 132-147.

Mane-Kapaj, A., Kapaj, I., Chan-Halbrendt, C. and Totojani, 0. (2010). Assessing the comparative advantage of Albanian olive oil production. International Food and Agribusiness Management Review, 13(1), 112.

Markou, M. and Kavazis, A. (2006). Market and trade policies for fruits, vegetables and olive oil - Cyprus's agricultural situation report. Agricultural Research Institute. Nicosia, Cyprus.

Masters, W. A. and Winter-Nelson, A. (1995). Measuring the comparative advantage of agricultural activities: Domestic resource costs and the social cost-benefit ratio. American Journal of Agricultural Economics, 77(2), 243-250

Mgeni, C. P., Sieber, S., Amjath-Babu, T. S. and Mutabazi, K. D. (2018). Can protectionism improve food security? Evidence from an imposed tariff on imported edible oil in Tanzania. Food Security, 10(4), 799-806.

Miah, M. M. and Rashid, M. A. (2015). Profitability and comparative advantage of oilseed production in Bangladesh. Bangladesh Development Studies, 38(3), 35-54.

Monke, E. A. and Pearson, S. R. (1989). The policy analysis matrix for agricultural development. Ithaca and London: Cornell University Press.

Quddus, M. A. and Mustafa, U. (2011). Comparative advantage of major crops production in Punjab: An application of policy analysis matrix. Lahore Journal of Economics, 16(1), 63-94.

Regmi, A. and Gehlhar, M. (2001). Consumer preferences and concerns shape global food trade. Food Review/National Food Review, 24(3), 2-8.

Sachithra, K. M. V., Sajeevi, G. A. C., Withanawasm, M. P. K. and Jayathilake, W. M. S. A. (2014). Comparative advantage in international trade: A study based on leading exports in Sri Lanka. Kelaniya Journal of Management, 1(2), 51-85.

Saerbeck, R. (1990). Economic appraisal of projects: Guidelines for a simplified costbenefit analysis. Cahiers BEI/EIB Papers, (15), 59-78.
Sahibzada, S., Hemachandra, D., Weerasooriya, S, A. and Weerahewa'J. (2020). "Trends and patterns of processed food exports from South Asia: An analysis of product and market diversification". Agricultural Tropical Research. 31(4), 65-90.

Samaratunga, P. and Thibbotuwawa, M. (2006). Customs mapping and analysis of South Asian agricultural trade liberalization effort. Asia-Pacific Research and Training Network on Trade (ARTNeT), Working paper series (No. 26), Bangkok.

Sartori, D., Catalano, G., Genco, M., Pancotti, C., Sirtori, E., Vignetti, S. and Bo, C. (2014). Guide to cost-benefit analysis of investment projects. Economic appraisal tool for cohesion policy 2014-2020. European Commission Directorate-General for Regional and Urban policy.

Shah, N. A., Aujla, K., M. Ishaq, M. and Farooq, A. (2013). Trends in sunflower production and its potential in increasing domestic edible oil production in Punjab, Pakistan. Sarhad Journal of Agriculture, 29(1), 7-13.

Shahabuddin, Q. and Dorosh, P. A. (2002). Comparative advantage in Bangladesh crop production. (MSSD Discussion Paper No. 47). International Food Policy Institute 2033 K Street, N.W. Washington, D.C. 20006 U.S.A.

Shinoj, P. and Mathur, V. C. (2008). Comparative advantage of India in agricultural exports vis-à-vis Asia: A post-reforms analysis. Agricultural Economics Research Review, 21(1), 60-66.

Squire, L. and Van der Tak, H. G. (1975). Economic analysis of projects. World Bank Publications.

Sultan, K. and Zainal Abidin, I. S. (2017). Assessing comparative advantage of Pakistan with United States of America: The role of Pakistan's export financial sector. International Journal of Academic Research in Accounting, Finance and Management Sciences, 7(1), 353-360.

Weiss, J. (2009). The economics of climate change in Southeast Asia: A regional review. Asian Development Bank. 



\section{APPENDICES}

Appendix Table 1: Products included in the edible oil sector

\begin{tabular}{|l|l|l|l|}
\hline \multicolumn{2}{|c|}{ Edible oils products } & \multicolumn{1}{c|}{ CPC code } & \multicolumn{1}{c|}{ HS code } \\
\hline Animal Fats & Animal fats, un-rendered & 215 & $\begin{array}{l}0209,1502,1505, \\
1506,1501,1504, \\
1503,1516\end{array}$ \\
\hline Vegetable Oils & $\begin{array}{l}\text { Soya bean oils, Groundnut oil, } \\
\text { Sunflower seed oil, Rape, colza and } \\
\text { mustard oil, palm oil, coconut oil, } \\
\text { olive oil, cottonseed oil, other } \\
\text { vegetable oils }\end{array}$ & 216 & $\begin{array}{l}1507,1508,1512, \\
1514,1513,1509, \\
1510,1516.20,\end{array}$ \\
\hline $\begin{array}{l}\text { Margarine and } \\
\text { similar } \\
\text { preparations }\end{array}$ & Margarine and similar preparations \\
\hline $\begin{array}{l}\text { Oil-cake and } \\
\text { other residues }\end{array}$ & 217 & 1517 \\
\hline
\end{tabular}

Source: Compiled by the Authors, based on the GTAP database, version 10 .

Note: HS (Harmonized System) Codes of commodities, CPC: Central Product Classification

Appendix Table 2: Aggregation of tradable inputs

\begin{tabular}{|l|l|l|l|}
\hline Aggregate inputs & & CPC code & ISIC4 \\
Code
\end{tabular}




\begin{tabular}{|l|l|l|l|}
\hline & Manufacture of basic iron and steel & & 24 \\
& Manufacture of fabricated metal products & 25 \\
\hline \multirow{2}{*}{$\begin{array}{l}\text { Wearing } \\
\text { manufacture }\end{array}$} & Manufacture of textiles & & 13 \\
& Manufacture of wearing apparel & & 14 \\
& Manufacture leather & 15 \\
& Manufacture of wood & 16 \\
& Manufacture of paper & 17,18 \\
\hline $\begin{array}{l}\text { Electronic } \\
\text { manufacture }\end{array}$ & Manufacture of computer and electrical & & $26-31$ \\
\hline
\end{tabular}

Source: Compiled by the Authors, based on the GTAP database, version 10.

Note: In the GTAP database agricultural and food processing sectors are defined according to the Central Product Classification (CPC) and the other sectors are defined according to the International Standard Industry Classification (ISIC).

\section{Appendix 3. Path adopted in deriving social prices.}

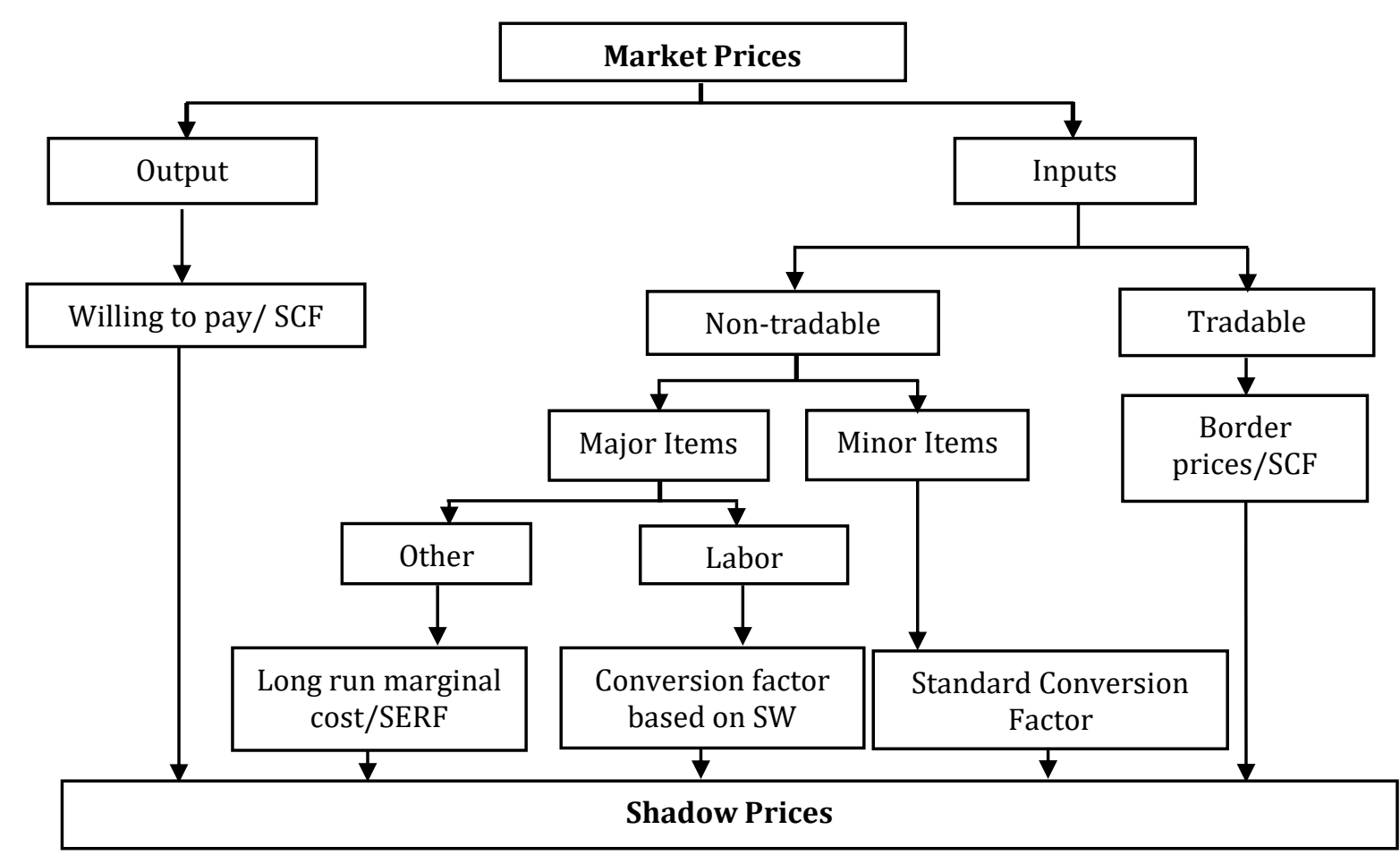

Source: Adapted from Saerbeck (1990), and Sartori (2014)

Appendix Table 4: Conversion factors for calculation of the social price of inputs and output

\begin{tabular}{|l|l|l|}
\hline Inputs & The formula of conversion factor & Elements of formula \\
\hline $\begin{array}{l}\text { Tradable, } \\
\text { minor non-tradable } \\
\text { inputs and outputs }\end{array}$ & $S C F=\frac{1}{(M+X)}$ & $\begin{array}{l}\text { M= Total value of import in CIF price } \\
\text { X= Total value of export in FOB price } \\
\text { TM= Total value of duties on import } \\
\mathrm{TX}=\text { Total value of export tax- subsidies }\end{array}$ \\
\hline Skilled labor & $\begin{array}{l}\text { Perfect Market, SWR=1 } \\
\text { Imperfect Market, SWR }=0.5,1.5\end{array}$ & $\begin{array}{l}\text { W= Market wage } \\
\mathrm{t}=\text { income taxation } \\
\mathrm{u}=\text { unemployment }\end{array}$ \\
\hline Un-skilled labor & $S W=W \times(1-t) \times(1-u)$ & $\begin{array}{l}\mathrm{t}=\text { average rate of tax } \\
\mathrm{s}=\text { average rate of subsidy }\end{array}$ \\
\hline Capital & $S E R F=1 \times(1+t-s)$ & \multicolumn{2}{|l}{} \\
\hline
\end{tabular}

Source: Adapted from Saerbeck (1990), and Sartori (2014) 
Appendix Table5. Import taxes for tradable inputs in South Asia in 2014.

\begin{tabular}{|c|c|c|c|c|c|c|c|c|c|c|c|c|}
\hline \multicolumn{2}{|c|}{$\begin{array}{ll}\text { Importers } & \text { Exporters } \\
\end{array}$} & Bangladesh & India & Pakistan & $\begin{array}{c}\text { Sri } \\
\text { Lanka }\end{array}$ & RSA & $\begin{array}{c}\text { Saudi } \\
\text { Arabia }\end{array}$ & Indonesia & Malaysia & Argentina & Brazil & ROW \\
\hline \multirow{6}{*}{ 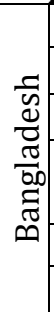 } & Plant sources & 0.00 & 2.76 & 0.54 & 5.32 & 0.00 & 12.45 & 17.68 & 14.43 & 0.33 & 3.28 & 5.00 \\
\hline & Animal sources & 0.00 & 5.11 & 24.49 & 2.50 & 0.00 & 9.96 & 4.95 & 5.47 & 4.99 & 0.00 & 5.28 \\
\hline & Processed food & 0.00 & 9.70 & 8.84 & 6.73 & 0.00 & 7.49 & 11.58 & 11.84 & 0.05 & 5.98 & 5.88 \\
\hline & $\begin{array}{l}\text { Extraction and heavy } \\
\text { manufactures }\end{array}$ & 0.00 & 7.93 & 6.58 & 12.58 & 0.00 & 3.74 & 8.37 & 10.47 & 5.63 & 6.11 & 5.44 \\
\hline & Wearing manufactures & 0.00 & 13.01 & 15.59 & 11.38 & 0.00 & 10.22 & 11.34 & 19.01 & 4.90 & 23.24 & 11.22 \\
\hline & Electronic manufactures & 0.00 & 10.90 & 11.12 & 9.78 & 0.00 & 3.92 & 12.80 & 8.87 & 7.75 & 2.51 & 5.60 \\
\hline \multirow{6}{*}{ 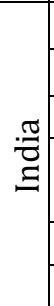 } & Plant sources & 7.04 & 0.00 & 19.60 & 23.01 & 13.92 & 28.20 & 43.55 & 5.04 & 30.51 & 26.85 & 10.50 \\
\hline & Animal sources & 2.34 & 0.00 & 4.60 & 0.00 & 2.99 & 2.35 & 23.40 & 23.78 & 5.45 & 22.92 & 5.01 \\
\hline & Processed food & 8.23 & 0.00 & 23.72 & 2.78 & 38.46 & 23.26 & 70.86 & 80.40 & 0.57 & 39.10 & 3.18 \\
\hline & $\begin{array}{l}\text { Extraction and heavy } \\
\text { manufactures }\end{array}$ & 1.93 & 0.00 & 4.15 & 2.30 & 0.07 & 1.15 & 4.28 & 3.90 & 1.86 & 2.65 & 3.53 \\
\hline & Wearing manufactures & 1.93 & 0.00 & 8.95 & 1.80 & 0.49 & 10.10 & 9.02 & 9.60 & 7.14 & 8.40 & 8.32 \\
\hline & Electronic manufactures & 0.99 & 0.00 & 6.89 & 0.00 & 1.29 & 8.07 & 8.18 & 4.88 & 7.33 & 6.61 & 7.69 \\
\hline \multirow{6}{*}{$\begin{array}{l}\frac{\pi}{\pi} \\
\frac{\pi}{\pi} \\
\frac{\pi}{\pi} \\
\Sigma\end{array}$} & Plant sources & 1.64 & 2.15 & 0.00 & 4.38 & 9.30 & 24.64 & 9.22 & 0.07 & 1.04 & 1.36 & 3.84 \\
\hline & Animal sources & 4.44 & 4.16 & 0.00 & 0.00 & 1.13 & 3.10 & 2.64 & 0.00 & 4.70 & 6.01 & 1.26 \\
\hline & Processed food & 5.66 & 7.19 & 0.00 & 0.80 & 5.54 & 19.60 & 8.31 & 7.39 & 9.68 & 9.46 & 15.70 \\
\hline & $\begin{array}{l}\text { Extraction and heavy } \\
\text { manufactures }\end{array}$ & 5.97 & 6.54 & 0.00 & 1.21 & 2.88 & 2.56 & 8.18 & 8.75 & 13.77 & 6.57 & 6.37 \\
\hline & Wearing manufactures & 11.32 & 6.02 & 0.00 & 2.46 & 9.15 & 12.57 & 12.30 & 10.69 & 1.19 & 10.27 & 10.65 \\
\hline & Electronic manufactures & 2.58 & 4.31 & 0.00 & 1.86 & 7.76 & 3.51 & 30.34 & 10.20 & 11.96 & 23.62 & 9.02 \\
\hline \multirow{6}{*}{ 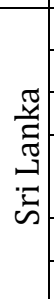 } & Plant sources & 54.54 & 21.82 & 33.84 & 0.00 & 0.97 & 14.91 & 40.11 & 6.12 & 14.53 & 34.01 & 21.89 \\
\hline & Animal sources & 0.00 & 0.24 & 0.10 & 0.00 & 0.00 & 23.59 & 0.00 & 24.97 & 0.00 & 0.00 & 2.63 \\
\hline & Processed food & 10.96 & 19.01 & 0.55 & 0.00 & 3.01 & 17.82 & 40.95 & 37.77 & 37.10 & 14.34 & 21.97 \\
\hline & $\begin{array}{l}\text { Extraction and heavy } \\
\text { manufactures }\end{array}$ & 1.27 & 6.37 & 11.28 & 0.00 & 1.30 & 4.84 & 4.43 & 6.98 & 0.63 & 9.99 & 5.03 \\
\hline & Wearing manufactures & 4.96 & 1.00 & 0.06 & 0.00 & 4.39 & 8.78 & 5.82 & 2.43 & 1.10 & 7.11 & 2.88 \\
\hline & Electronic manufactures & 22.89 & 2.25 & 6.01 & 0.00 & 5.21 & 8.47 & 11.16 & 9.95 & 1.61 & 4.63 & 3.51 \\
\hline
\end{tabular}

Source: Compiled by the Authors, based on the GTAP database, version 10. 